\title{
The Politics of Affirmative Consent: Considerations from a Gender and Sexuality Studies Perspective
}

\author{
Rona Torenz \\ Research Assistant, Fulda University of Applied Sciences, Fulda, Germany \\ Corresponding author: rona.torenz@gmx.net
}

(Received 16 June 2021; accepted 17 June 2021)

\begin{abstract}
While "no means no" considers sex as consensual until someone says no, "yes means yes" defines sex only then as consensual when all parties have explicitly agreed. Consent is thus positively determined by the presence of a yes and no longer negatively determined by the absence of a no. "Yes means yes" thus not only sets the limit as to when sex becomes sexual violence, it also tells us how morally "correct" sex should look like. In the first part I will give an insight into debates about affirmative consent in the US and Germany. In the following, I will work out how affirmative consent misjudges the subjectifying functioning of sexual power relations. I will show that the understanding of affirmative consent is based on a gendered giverreceiver grammar of consent, which stabilizes heteronormative notions of female sexuality as passive and male sexuality as active. Based on the results of conversational analytical studies on sexual communication, I will argue that the politics of affirmative consent underestimates the internalization of heteronormative discourses in sexual subjects.
\end{abstract}

Keywords: sexual consent; sexuality; gender; heteronormativity; sexual communication

\section{"[C]ontext is where consent is getting political."}

The introduction of the "No means No" standard in German penal code in 2016 was welcomed by many sides as a consistent implementation of feminist demands and thus of the right to sexual autonomy. ${ }^{2}$ Yet "No means No" has not been considered a contemporary standard in feminist debates for a while now when it comes to the determination of sexual consent. Since as late as the early 1990s, the concept of "No means No" has been further developed in the direction of "only Yes means Yes." Whereas with "No means No," sex is considered consensual until one

Parts of this contribution are based on the author's monograph: RonA ToREnZ, "JA HEIßT JA"? FEMINISTISCHE DeBATTEN UM EINVERNEHMLICHEN SEX (2019).

${ }^{1}$ Kate Lockwood Harris, Yes Means Yes and No Means No, but Both These Mantras Need to go: Communication Myths in Consent Education and Anti-Rape Activism, 46, J. OF Applied COMM. Res. 155, 167 (2018).

${ }^{2}$ Press Release, Bundesverband Frauenberatungsstellen und Frauennotrufe (bff), Nein heißt nein! Paradigmenwechsel im Sexualstrafrecht (July 7, 2016) (on file with author); Press Release, Deutscher Juristinnenbund e.V. (djb), djb begrüßt Paradigmenwechsel im Sexualstrafrecht: "Nein heißt Nein!" wird endlich Gesetz (July 7, 2016) https://www.djb.de/presse/ pressemitteilungen/detail/pm16-20.

(C) The Author(s) 2021. Published by Cambridge University Press on behalf of the German Law Journal. This is an Open Access article, distributed under the terms of the Creative Commons Attribution licence (http://creativecommons.org/licenses/by/4.0/), which permits unrestricted re-use, distribution, and reproduction in any medium, provided the original work is properly cited. 
person says no, with "Yes means Yes," sex is only defined as consensual when all participants have explicitly agreed. In other words, consent is no longer assumed to be the default value in sexual situations. Here, agreement is defined positively by the presence of a yes and no longer negatively by the absence of a no. The concept is therefore also called affirmative consent.

In contrast to "No means No," which defines the circumstances under which sex should be criminalized as sexual violence and leaves open what "morally correct" sex could look like, Yes means Yes makes positive statements about what "good" sex should contain ${ }^{3}$. The affirmative consent approach relies on a contract-like model of negotiation in sex and thus implicitly devalues other forms of sexuality. Affirmative consent thus risks establishing a new sexual norm. ${ }^{4}$ It is therefore important to think not only about the legal effects of affirmative consent, but also about its implications for every-day sexual practices and moral beliefs. In this Article, affirmative consent is primarily considered as a social discourse and therefore as a result of cultural and social practices, which produces knowledge within existing power relations. ${ }^{5}$ This knowledge can have stabilizing or transformative effects - or both—on these power relations. ${ }^{6}$ Therefore, affirmative consent as a critical discourse can thus reproduce heteronormative notions of sexuality and gender in particular. According to Foucault, the more covertly power mechanisms can operate, the more successfully they can prevail. ${ }^{7}$ This means that exposing power mechanisms can have a fragile effect on them. The aim of this Article is therefore to draw out the power-stabilizing moments of affirmative consent on the basis of three key considerations, in order to be able to challenge them.

\section{A. The Rise of Affirmative Consent Regulations}

In 1991, pressure from the feminist campus group Womyn of Antioch at Antioch College in Yellow Springs, Ohio led to the introduction of an affirmative consent-based regulation on the campus in order to prevent sexual violence. ${ }^{8}$ The Sexual Offense Prevention Policy (SOPP) ${ }^{9}$ at the college in Ohio has since stipulated that all parties must give their consent prior to any sexual contact. The SOPP regulations contain the seven characteristics that essentially make up affirmative consent to this day:

(1) Explicitness: Consent must be expressed verbally in advance. Silence does not mean consent. Unconscious or sleeping persons cannot give consent in accordance with the requirement of explicitness.

(2) Voluntariness: Consent must be given voluntarily, without pressure or coercion.

(3) Ability to consent: All persons involved must be able to give consent. ${ }^{10}$ Accordingly, heavily intoxicated and drunk persons cannot consent, nor can persons under a certain age.

(4) Shift of responsibility: The person who initiates a sexual act has the responsibility to obtain the consent of all participants, regardless of their relationship and sexual history.

\footnotetext{
${ }^{3}$ The literature on what constitutes good sex cannot be given sufficient attention here. For a first insight, see Lois Pineau, Date Rape. A Feminist Analysis, 8 LAW \& PHIL. 217 (1989). For a communicative model of sexuality, or the reflections of John Gardner see John Gardner, The Opposite of Rape, 38 OXFORD J. OF LEGAL STUD. 48 (2018).

${ }^{4}$ Tanya Serisier, Is Consent Sexy?, B A M N, 2014, at 6.

${ }^{5}$ Jutta Hartmann, Der heteronormative Blick in wissenschaftlichen Diskursen—eine Einführung, in HETERONORMATIVITÄT. Empirische Studien zU Geschlecht, Sexualität und Macht, 55 (Jutta Hartmann \& Bettina Fritzsche eds., 2007).

${ }^{6} I d$.

${ }^{7} I d$. at 57 .

${ }^{8}$ Nicolas Mills, How Antioch College Got Rape Right 20 Years Ago, The DaILY BeAst, Dec. 10, 2014, http://www. thedailybeast.com/articles/2014/12/10/how-antioch-solved-campus-sexual-offenses-two-decades-ago.

${ }^{9}$ See Antioch College, Student Handbook 66 (2018), https://3e5gfv4e3o124d3vv21aphkp-wpengine.netdna-ssl.com/ wp-content/uploads/2019/03/Student-Handbook-2018.pdf.

${ }^{10} I d$. at 66 ("In order for affirmative consent to be valid, all parties must have unimpaired judgment.").
} 
(5) Freedom from presumption: Consent must be obtained repeatedly for each new sexual activity. Consent may not be assumed because consent has already been given for another sexual act.

(6) Informedness: All participants must know what consent is being given for in particular. A simple "May I?" is therefore not sufficient.

(7) Revocability: A previously given consent can be withdrawn at any time. ${ }^{11}$

Since the introduction of the SOPP at Antioch College, many legal regulations based on affirmative consent have been introduced in the U.S. and worldwide; for example, affirmative-consentregulations have been introduced at over 1,400 US institutions of higher education. ${ }^{12}$ Since 2014, public colleges in California are required to establish affirmative consent standards on their campuses in order to get state funding. Furthermore, in 2015 California introduced affirmative consent trainings in the sex education curriculum of all public high schools. ${ }^{13}$ College policies in the U.S. are often accompanied by mandatory educational measures such as affirmative consent training and the like, which students at colleges must complete during their studies. ${ }^{14}$

In the penal codes of some European countries, sexual offenses are defined by the lack of affirmative consent. ${ }^{15}$ In Great Britain, sexual acts are punishable if the victim does not consent and there is no reasonable justification to assume that he or she did consent. According to the Sexual Offences Act of England, a person consents, "if he agrees by choice, and has the freedom and capacity to make that choice." ${ }^{\text {16 }}$ At the end of 2017, Sweden tightened its sexual offenses law. Since then, it has been a criminal offense to perform sexual acts "with a person who is not participating voluntarily." Furthermore, it is said: "When assessing whether participation is voluntary or not, particular consideration is given to whether voluntariness was expressed by word or deed or in some other way." ${ }^{17}$ Grapperhaus, the Dutch Minister of Justice, announced in May 2019 that he would make non-consensual sex a punishable offense in the Netherlands based on an affirmative consent standard:

No means No. Absence of 'No' does not mean 'Yes'. If the other person does not speak out clearly, you must first find out whether he or she actually wants sexual contact. This inability to express oneself occurs when someone 'becomes numb' with fear. Another sign is if the person stops participating in the act at any time. A hesitant or changed attitude is a signal. In future, in cases of doubt, there is an obligation to investigate further and affirm consent. ${ }^{18}$

In 2020, the Spanish and Danish Governments also announced plans to change sexual offense legislation towards an affirmative consent approach. ${ }^{19}$

\footnotetext{
${ }^{11}$ For all characteristics described see id.

${ }^{12}$ For the estimate of the National Center for Higher Education Risk Management see Sandy Keenan, Affirmative Consent: Are Students Really Asking?, N. Y. TimES, July 28, 2015, https://www.nytimes.com/2015/08/02/education/edlife/affirmativeconsent-are-students-really-asking.html.

${ }^{13}$ Jennifer Medina, Sex Ed Lesson: 'Yes Means Yes,' but It's Tricky, N.Y. Times, Oct. 14, 2015, https://www.nytimes.com/ 2015/10/15/us/california-high-schools-sexual-consent-classes.html.

${ }^{14} I d$.

${ }^{15}$ For an overview see Natalie Greenfield, Legislative Approaches To Rape In The EU: Outlining Case Study Examples, GENPol, Nov. 7, 2019, https:/gen-pol.org/2019/06/legislative-approaches-to-rape-in-the-eu-outlining-case-study-examples/.

${ }^{16}$ Sexual Offences Act 2003, c.42, $\$ 74$ (UK), https://www.legislation.gov.uk/ukpga/2003/42/contents.

${ }^{17}$ Brottsbalken [BRB] [Penal CODE], 6:1 (Swed.), https://www.government.se/498db0/contentassets/ 7a2dcae0787e465e9a2431554b5eab03/the-swedish-criminal-code.pdf.

${ }^{18}$ Ministry of Just. \& SeCurity of The NetH., Non-Consensual Sex and Sexual Harassment Become Punishable, May 22, 2019, https://www.government.nl/latest/news/2019/05/22/non-consensual-sex-and-sexual-harassment-become-punishable.

${ }^{19}$ Spain Plans 'Only Yes Means Yes' Rape Law, BBC News, Mar. 3, 2020, https://www.bbc.com/news/world-europe51718397; Reinhard Wolff, Künftig heißt nur Ja wirklich Ja, TAZ, Sept. 9, 2020, https://taz.de/Sexualstrafrecht-inDaenemark/!5712066/.
} 
The approach of affirmative consent has also been incorporated into the Council of Europe Convention on preventing and combating violence against women and domestic violence. ${ }^{20}$ The so-called Istanbul Convention stipulates that all non-consensual sexual acts are to be made punishable, with states being encouraged to make arrangements, "which encompasses the notion of lack of freely given consent." 21 This formulation can be interpreted in the way that the criminalization of sexual acts in which a positively determined consent is lacking-Yes means Yes-is preferable to the criminalization of sexual acts in which a no is expressed-No means No. The Istanbul Convention further emphasizes that the circumstances under which consent is given should be included in criminal prosecution and that evidence should therefore be judged according to its context. ${ }^{22}$ It should also be ensured "that interpretations of rape legislation and the prosecution of rape cases are not influenced by gender stereotypes and myths about male and female sexuality." 23

From a gender-critical perspective, these references are certainly commendable. People do not make decisions about sexual consent in a vacuum but in social contexts. As I will show, these contexts are structured by heteronormative and gendered power relations. As stated in the Istanbul Convention, these and other contextual factors must be appropriately acknowledged in each individual case.

First, I will explain the theoretical concepts of gender, sexuality and heteronormativity on which the following considerations are based. Second, I will elaborate on three points that are relevant for a contextual understanding of affirmative consent that takes power relations into account: (1) The concept of affirmative consent is based on a giver-receiver grammar according to which one person receives consent and another gives it. Such an understanding of consent corresponds to heteronormative concepts of male sexuality as active-initiating and female sexuality as reactive-receptive. In this way, traditional gender roles of female vulnerability, powerlessness, and potential victimhood can be stabilized in contrast to male protection, agency, and potential perpetration. (2) The affirmative consent approach requires individuals to communicate directly and unambiguously in sexuality. This requirement is based on the assumption that miscommunication is a cause of sexual violence. Conversational analytical studies show that a clear and unambiguous yes is not necessary to understand consent or rejection in sexual encounters. (3) The affirmative consent approach assumes that a yes expresses consent. However, this disregards scientific findings on sexual compliance. Sexual compliance is consent to unwanted sex. Women in particular tend to feel obliged to consent to sex in certain situations. This may have to do with external power relations, but also with internalized heteronormative discourses.

\section{B. Theoretical Framework: Gender - Sexuality - Heteronormativity}

For the present Article, the concept of heteronormativity is central. Judith Butler describes the heterosexual matrix as a "grid of cultural intelligibility through which bodies, gender and desires are naturalized." 24 She understands both gender and sex as socially constructed. Thus, when this Article refers to "men" and "women," it is not referring to biological, "natural" facts, but rather to

\footnotetext{
${ }^{20}$ Convention on Preventing and Combating Violence Against Women and Domestic Violence, May 11, 2011, C.E.T.S. No. $210 \mathrm{https} / / \mathrm{rm}$.coe.int/CoERMPublicCommonSearchServices/DisplayDCTMContent?documentId=090000168008482e [hereinafter ISTANBUl CONVENTION].

${ }^{21}$ Id. at nr. 193.

${ }^{22}$ Id. at nr. 192.

${ }^{23} I d$.

${ }^{24}$ Judith Butler, Gender Trouble: Feminism And the Subversion of Identity 208 (Linda J. Nicholson ed., 2015) (1990).
} 
constructions that are permanently produced by powerful practices, symbolic orders, economic inequalities, and doing gender, and thus become material, but not inevitable. ${ }^{25}$

Furthermore, Butler states, "that for bodies to cohere and make sense there must be a stable sex expressed through a stable gender (masculine expresses male, feminine expresses female) that is oppositionally and hierarchically defined through compulsory practice of heterosexuality." 26 Heteronormativity essentially refers to the totality of all those mechanisms that set heterosexual desire between women and men as binary genders as "normal" and "natural" and in doing so produce heterosexuality and establish it as the social norm. Heteronormativity is thereby inscribed in all areas of society: It affects the constitution of subjects as gendered and sexually determined identities, regulates behavioral norms and knowledge production, structures discourses, and determines political action. ${ }^{27}$

In his volumes on the history of sexuality, Foucault describes how, with the emergence of capitalism, heteronormative forms of behavior were also coded as inward conditions and thus as normative "gender natures." Foucault understands sexuality as being shaped by discourses producing it as "knowledge of sex." 28

For Foucault, contrary to the repression hypothesis, oppression is not the constitutive element of the history of modern sexuality. Instead, he assumes that modern sexuality is normalized and regulated precisely not by being silent but by speaking about it. So instead of "bringing it out" from a place beyond discourse, we generate sexuality discursively through our speaking. Foucault calls this discourse strategy the "will to knowledge," for which the practice of confession is central. ${ }^{29}$ The obligation to confess appears not as the effect of coercion, but as a revelation of truth. Foucault describes here how speaking about sex is stimulated precisely by the fact that liberation is associated with it and thus remains hidden as a strategy of power.

The concept of affirmative consent also conveys the impression that negotiation of sexuality per se would be liberating, because it could lead to consensual agreement. This can, however, make the power relations that are at work in the negotiation process invisible. According to Rosemary Hennessy, subjects in today's neoliberal conditions usually experience their own sexual relationships as individual and thus hide the social structuring of their relationships through heteronormativity. ${ }^{30}$ Therefore, the present contribution is also concerned with revealing these hidden, heteronormative structures in the understanding of affirmative consent. Sexuality, like gender, is thus also not pre-social, but is created by society and thus affects the constitution of the subject. $^{31}$

For Hennessy, heteronormativity controls desire between a sexual subject and a sexual object. According to a gendered hierarchy, sexual subjects are constructed as male and stand above sexual objects, which in turn are considered female. ${ }^{32}$ Thus, men and women are differently positioned in heteronormative discourses.

The psychologist Wendy Hollway distinguishes between three heteronormative discourses:

\footnotetext{
${ }^{25}$ In the following, due to the given scope, the focus will be particularly on gendered modes of subjectivation in the field of sexuality and heteronormativity. However, reference should also be made to the large body of literature that deals even more fundamentally with epistemic questions about the connections of gender with conceptions, production and practice of knowledge. For an insight see Elizabeth Anderson, Feminist Epistemology and Philosophy of Science, in THE STANFORD EncyClopedia of Philosophy (Edward N. Zalta ed., 2000), https://plato.stanford.edu/archives/spr2020/entries/feminismepistemology.

${ }^{26}$ ButLER, supra note 24, at 208.

${ }^{27}$ Peter Wagenknecht, Was ist Heteronormativität? Zu Geschichte und Gehalt des Begriffs, in HeTERONORMATIVITÄT. Empirische Studien zU Geschlecht, Sexualität und Macht, 17, 17 (Jutta Hartmann \& Bettina Fritzsche eds., Rona Torenz trans., 2007).

${ }^{28} I d$. at $19-20$.

${ }^{29}$ Michel Foucault, The history of SeXuality 1. The will to KNOWledge, 59 (2020).

${ }^{30}$ Wagenknecht, supra note 27 , at 29.

${ }^{31} I d$. at 17 .

${ }^{32} I d$. at 18 .
} 
The male sexual drive discourse suggests that men have a biological, insatiable sex drive, are always looking for sex and need sexual satisfaction once they are aroused. Male desire is thereby understood as a "dominant driving force." ${ }^{33}$ Potency and virility are thus constructed as inherent and "natural" to the masculine, while femininity is associated with a lower desire. Women are attributed a gatekeeper role, being considered responsible for limiting and controlling male desire. Female sexual agency consists primarily in satisfying male sexuality. Hakvåg puts it pointedly: "The resulting gendered construction of sexuality and desire is the following: men desire sex; women should desire to be desired." 34 Through these heteronormative constructions, female desire becomes invisible or is simply considered non-existent. ${ }^{35}$

The have/hold discourse locates sex in the context of a monogamous relationship, with women being those who are looking more for a committed relationship. Here, sex can be understood as a means to keep or stabilize the relationship. Empirical findings show that women have often internalized this discourse by linking their own sexual desire to romantic relationships. ${ }^{36}$ In heterosexual relationships, they try to bind their male partners by sexual attractiveness and satisfaction. The sociologist Eva Illouz shows impressively, how the changed economy of liberalized marriage markets stabilizes existing economic and political power relations between men and women and led to an "emotional domination of men over women." 37

In the permissive discourse, both women and men are allowed to have sex outside of a love relationship and satisfy their sexual desires, but a version of sex is maintained that is embedded in the male sexual drive discourse. ${ }^{38}$ The old double standard, in which sex outside of marriage was only acceptable for men, was replaced by a new, conditional double standard, which tolerates sex outside of marriage but limits the conditions for it more strongly for women than for men. Women who have several sexual partners are namely tolerated, but still evaluated differently than promiscuous men. ${ }^{39}$

It can be stated, that " $\mathrm{t}]$ hrough these discourses, a restrictive set of subjectivities becomes available to women (and men) with little space for female-centred sexual activity that does not promote phallocentric (male) sexuality." 40

The far-reaching sexual liberalization in recent decades also has to be understood as a modernization process of those discourses, in which new gender-specific modes of subjectivation emerged. It is important to acknowledge, that those modes do not only structure the constitution of heterosexual subjects, but also non-heterosexual subjects as "rejected others." ${ }^{\text {"1 }}$ Butler states correspondingly that "the utopian notion of a sexuality freed from heterosexual constructs . . failed to acknowledge the ways in which power relations continue to construct sexuality for women even within the terms of a 'liberated' heterosexuality or lesbianism." ${ }^{2}$ To summarize,

\footnotetext{
${ }^{33}$ Wendy Hollway, Gender Difference and the Production of Subjectivity, in CHANGING THE SUBJeCt. PsYCHOLOGY, SOCIAL REgulation AND subjectivity 227 (Julian Henriques, Wendy Hollway, Cathy Urwin, Couze Venn \& Valerie Walkerdine eds., 1998).

${ }^{34}$ Hedda Hakvåg, Does Yes Mean Yes? Exploring Sexual Coercion in Normative Heterosexuality, 28 CANADIAN WOMAN STUD. 121 (2010).

${ }^{35}$ Hakvåg, supra note 34; Olga Burmakova, 50 Shades of Yes. Feminist Re-Conceptualization of SeXual Consent as Affirmative, Communicative, Enthusiastic (2013); Nicola Gavey, Technologies and Effects of Heterosexual Coercion, 2 FEMINISM \& Psychol. 325, 328-329 (1992); Hollway, supra note 33.

${ }^{36}$ See Wendy Hollway, Women's Power in Heterosexual Sex, 7 Women's STUd. InT'L F. 63, $63-65$ (1984); Hakvåg, supra note 34 , at $124-25$.

${ }^{37}$ Eva Illouz, Why Love Hurts. A Sociological Explanation (2013).

${ }^{38}$ See Melanie A. Beres \& Panteá Farvid, Sexual Ethics and Young Women's Accounts of Heterosexual Casual Sex, 13 SEXUALITIES 377, 379 (2010).

${ }^{39}$ See Hollway, supra note 36; Charlene L. Muehlenhard \& Marcia L. McCoy, Double Standard/Double Bind. The Sexual Double Standard and Women's Communication about Sex, 15 Psychol. OF Women Q. 447, 448 (1991).

${ }^{40}$ Muehlenhard \& McCoy, supra note 39, at 448.

${ }^{41}$ Wagenknecht, supra note 27 , at 18 .

${ }^{42}$ BUTLER, supra note 24 , at $40-41$.
} 
in heteronormativity "repression, the provision of patterns of understanding and instructions for action are condensed into normative conditions in which power is realized." ${ }^{33}$

\section{Active Men and Passive Women: The (Re-)Production of Heteronormativity}

In 2018 the journalist Courtney Sender published a text in the NEW YORK TIMES describing sexual encounters with a man who practices affirmative consent. ${ }^{44}$ At first, she finds it strange to be asked again and again for consent, but eventually she gets more and more used to it. When she also begins to ask him for consent, the following happens: "He was taken aback. 'I ask you that,' he said. 'Why?' 'Because I'm the one who could make you do something you don't want to do,' he said. 'Not vice versa."' 45 Her partner justifies his physical superiority as a man, which is why only he asks for consent-after all, a woman cannot harm him, because she is weaker. His reaction shows how the gender-specific distribution of roles is conceived in the concept of consent. That is why Sender asks herself, whether it mattered who was stronger: "Couldn't we treat each other as two equal human beings, each of whom had invited and agreed to intimate acts?"46 She tries to develop a perspective that ignores the gendered aspects in the affirmative consent approach and is based on the interaction between "two equal human beings."

Less obvious than in her story, however, gender roles are already structurally embedded in the affirmative consent approach. The philosopher John Kleinig defines the inner structure, or grammar, of consent as "A consented (to B) to [C]." ${ }^{47}$ Kleinig thus constructs consent as a reactive action: B proposes something and A gives-or refuses-consent in response. This structure can also be called "giver-receiver grammar" 48 in order to emphasize that one part gives and the other part receives consent.

In the affirmative consent approach, the initiator of the sexual act must ensure that consent is obtained. ${ }^{49}$ Thus, a major advantage of "Yes means Yes" over "No means No" is that the responsibility for sexual boundary violations is placed on the person who committed the violation.

This shift in responsibility is a consequence of the widespread idea that victims are, partly, to be blamed for what happened to them-they should have dressed differently, said more clearly no or defended themselves. Critics argue that "No means No" also implies such victim blaming, according to which individuals bear responsibility in defending their boundaries actively with a no.

In regulations based on a "No means No," the main question is how and whether peopleoften women-have said no clearly and unambiguously, and thus the behavior of victims is focused on. ${ }^{50}$ Similarly in the new German sexual offence law, the criterion is whether the opposing will of the victim was recognizable (erkennbar). In contrast to this, in the context of "Yes means Yes" it is now a matter of clarifying how and whether the accused, as initiator and thus as a potential perpetrator, has obtained and perceived consent. For only in this case would his or her actions be classified as consensual. Here, the behavior and the perception of the accused stands in the focus of interest.

\footnotetext{
${ }^{43}$ Wagenknecht, supra note 27, at 25.

${ }^{44}$ Courtney Sender, He Asked Permission to Touch, but Not to Ghost, N.Y. TimEs, Sept. 7, 2018, https://www.nytimes.com/ 2018/09/07/style/modern-love-he-asked-permission-to-touch-but-not-to-ghost.html.

${ }^{45} \mathrm{Id}$.

${ }^{46} \mathrm{Id}$.

${ }^{47}$ John Kleinig, The Nature of Consent, in The Ethics of Consent 3, 5 (Franklin Miller \& Alan Wertheimer eds., 2009).

${ }^{48}$ Eleanor Greenhalgh, The Groan Zone. Towards a Radical Grammar of Consent for Horizontal Collaboration, 11 (2013), http://eleanorg.org/sites/eleanorg.org/files/theGroanZone.pdf.

${ }^{49}$ For an overview of the different regulations that clearly assign responsibility to the sex proponent to ensure affirmative consent see Aya Gruber, Consent Confusion, 38 CARdozo L. Rev. 415, 434 (2016).

${ }^{50}$ Anastasia Powell, Amor Fati? Gender Habitus and Young People's Negotiation of (Hetero)sexual consent, 44 J. OF Soc. 167, 170 (2008). See also Moira Carmody, Sexual Ethics and Violence Prevention, 12 Soc. \& LEGAL STUD. 199 (2003).
} 
Because the requirement within the affirmative consent approach to ask for consent each time anew and to respect the boundaries of the opposite part was developed to avoid victim blaming. The initiators of sexual acts and thus those who are supposed to ask for consent are conceived as male. In contrast, the role of the gatekeeper, who gives or refuses consent and therefore limits or allows sexual contact, is constructed as female. The giver and receiver positions in the grammar of affirmative consent are gendered and the affirmative consent approach thus reproduces heteronormative notions of male and female sexuality.

The one-sided shift of responsibility to the initiating - as male constructed-part implies the image of powerless women who are "dependent" on the responsible and self-reflective interaction of men. This is particularly relevant in the context of affirmative consent standard, because they work in two directions. On the one hand, "Yes means Yes" makes statements about what proper sex should look like-how consent should be established: Explicitly and thus as clearly and directly as possible. Thus, the question of who bears preventive responsibility for reaching agreement is concerned with the responsibility for the sexual act as a potential violation of boundaries. At the same time, the argument against victim blaming does not revolve around potential but rather around concrete assaults that have already occurred and the question of who bears responsibility for them.

The argument of shifting responsibility requires a giver-receiver grammar of consent, because the argument is based on the notion that there is one person who is responsible for obtaining the consent of another person. This implies the assumption that in sexual acts there is an active-initiating and a reactive-receiving part, both of which are gender connotated within heteronormative discourses.

The giver-receiver-grammar of affirmative consent must be interpreted as already gendered against the background of heteronormative conceptions within society. Accordingly, an active male subject seeks the consent of a reactive female subject. ${ }^{51}$ One of the consequences of these gendered attributions is that male consent is assumed. This can lead to women seeing themselves less responsible for obtaining consent.

In a study from 2010, the agency of women in casual sex encounters was examined and here the focus was directed to how these women act "ethically." The authors refer to the concept of ethics in Foucault's work as a practice of self-creation. ${ }^{52}$ Freedom is thereby an important condition for ethical agency. The authors state that people are more or less restricted in their freedoms depending on their social position and thus in their possibilities to act ethically. The study shows that heteronormative discourses can limit the possibilities of women to act ethically within sexual encounters. At the same time, they find different strategies among the interviewees that not only encourage heteronormative discourses, but also disrupt and question them. One field of sexual ethics is "care for others." According to the study, this topic played the least important role in the descriptions of women. The main focus was on narratives related to securing the consent of the male partner. For example, two of the women interviewed described how they tried in various verbal and non-verbal ways to find out whether the sex was consensual. The authors interpreted this as follows:

These two women subtly disrupt the male sexual drive discourse by engaging in this type of checking .... No other women questioned their partner's desire or readiness for casual sex in this way. Considering the prevalence of the male sexual drive discourse, it is not surprising that there were relatively few accounts of this type of 'care for the other' in the women's casual sex stories. ${ }^{53}$

\footnotetext{
${ }^{51}$ Greenhalgh, supra note 48 , at 11 .

${ }^{52}$ Beres \& Farvid, supra note 38 , at 378.

${ }^{53}$ Beres \& Farvid, supra note 38 , at 389.
} 
Men are considered to be permanently desiring and therefore initiating sexual acts. This puts women in the position of reacting only to men and setting boundaries or deciding whether they want to participate or not. It leaves correspondingly little space for the conception and recognition of female desire and the initiation of sex by women and corresponds with heteronormative conceptions of sexuality of the male sexual drive discourse described above. ${ }^{54}$

At the same time, a gender-neutral understanding of the grammar of consent is too-shortsighted and "fails to consider gendered power relations." 55 These considerations result in the known area of tension between the ignorance of power relations and their fixation. Gendered attributions can be hidden by a gender-neutral interpretation, or gender inequalities can be fixed by naming them according to the power relations and deviating constellations remain unnoticed.

The grammar of consent described above assumes a person who "gives" sex and another person who "gets" sex. Both the "No means No" principle and affirmative consent do not question this giver-receiver grammar. The one-sided shift of responsibility can have a stabilizing effect on traditional gender conceptions by which women are victims with less options for action and men are powerful actors. It can establish female sexuality as passive/reactive and male sexuality as active/ initiative and thus ultimately promote a selective and gendered perception of sexuality and sexual violence.

\section{The Dogma of Direct Communication and the Miscommunication Myth}

Antioch College's SOPP requires that consent has to be given verbally: “The person who initiates sexual conduct is responsible for verbally asking for the affirmative consent of individual(s) involved. The person with whom sexual conduct is initiated must verbally express affirmative consent or lack of 'consent." 56 In exceptional cases, non-verbal signals can also express consent, but this must be verbally negotiated in advance: "Use of agreed upon forms of communication such as gestures or safe words is acceptable but must be discussed and verbally agreed to by all parties before sexual activity occurs." ${ }^{27}$ Under Swedish criminal law, consent can be given "by word or deed or in some other way." ${ }^{58}$ Whether verbal or non-verbal signals are accepted, affirmative consent approaches tend to prefer direct and unambiguous communication to ambivalent and indirect signals. ${ }^{59}$

In debates on the question of a verbalization requirement for affirmative consent, a common argument is that non-verbal communication leads to more misunderstandings and misinterpretations than direct, verbal communication. The demand for clarity and directness in communication encourages the idea that less clear communication leads to misunderstandings, which in turn could result in sexual assault or violence. The miscommunication hypothesis suggests that sexual assault occurs because the refusal of the victim has in some way remained undetected or misunderstood. ${ }^{60}$ In this logic, sexual violence is understood as an extreme example of miscommunication between people who are not capable of interpreting their signals correctly.

\footnotetext{
${ }^{54}$ Melanie A. Beres, 'Spontaneous' Sexual Consent. An Analysis of Sexual Consent Literature, 17 FemINISM \& PsYCHOL. 93, 97 (2007).

${ }^{55} \mathrm{Id}$. at $96-97$.

${ }^{56}$ ANTIOCH COLLEGE, supra note 9, at 66.

${ }^{57} I d$. Strictly speaking, it is questionable whether this regulation is still the concept of affirmative consent. After verbal agreement on certain safe words, consent is assumed until a person uses a safe word or expresses his or her no in some other way, however agreed upon. In practice, this corresponds to "No means No". It does not meet the criteria of shift of responsibility, informedness, or freedom from presumptions.

${ }^{58}$ Brottsbalken [BrB] [Penal Code], supra note 17.

${ }^{59}$ See, e.g., Rona Torenz, "Ja heißT JA"? Feministische Debatten um einvernehmlichen Sex 75 (2019).

${ }^{60}$ Melanie Beres, Sexual Miscommunication? Untangling Assumptions About Sexual Communication Between Casual Sex Partners, 12 Culture Health \& SeXuality 1 (2010).
} 
The sociolinguist Deborah Tannen provided the theoretical foundation for this hypothesis. ${ }^{61}$ Tannen's theory is that men and women grow up in two different and separate communication cultures and that the resulting lack of familiarity with the respective opposite-sex communication style leads to miscommunication. ${ }^{62}$ Tannen's model has been criticized for drawing a deficient picture of female communication and providing excuses for male language behavior. ${ }^{63}$ Therefore, the model allows "to emphasize issues of difference over issues of unequal power." 64 The over-thematization of differences thus serves the reproduction of hierarchical gender relations. While, according to the model of miscommunication, men understand a woman's no as a yes because this is what they have learned in their same-sex contexts, feminists argue that the concept of miscommunication serves more to justify and excuse the ignorance of a no. ${ }^{65}$

Different results are available on the question as to whether there are gender-specific differences in the communication of sexual consent. ${ }^{66}$ The relevant question is whether these differences in communication styles can lead to unintentional sexual violence. Although studies on sexual communication describe modes of communication as gendered, they nevertheless assume that these are mutually understood, as different communication strategies are available to all people, and that they can use these strategies depending on context and communicative goal. ${ }^{67}$ In practice sexual consent and refusal are not often communicated directly and verbally but rather non-verbally and indirectly. ${ }^{68}$ Not only in the context of sexuality, but in everyday life in general, the direct communication of a no is perceived as difficult: "It is common for people to experience difficulty in refusing invitations or declining offers, at whatever age, and across a wide variety of situations." 69

It is general cultural practice to articulate rejection implicitly and indirectly, with white lies, excuses and the like, so as not to hurt the other person. People often express a "no" in a way that they would like to, but cannot, because external circumstances prevent it. The famous excuse that one has a headache to say that one does not want sex is a good example of how this communicative norm is also deployed in sexual situations.

As can be shown, young men are quite capable of understanding sexual refusal through the most subtle communication strategies that are also used in everyday life. These include pauses extended by fractions of a second, curtness, specific body language, clichéd answers, apologies, mitigations, and relativizations. ${ }^{70}$ They also use such strategies themselves to express rejection. ${ }^{71}$

\footnotetext{
${ }^{61}$ Deborah Tannen, You Just Don't Understand. Women and Men in Conversation (2013).

${ }^{62}$ Id. at $23-48$.

${ }^{63}$ Alice F. Freed, We Understand Perfectly. A Critique of Tannen's View of Cross-Sex Communication, in LocATING POWER. Proceedings of the Second Berkeley Women and Language Conference 144, 145-46 (Kira Hall, Mary Bucholtz \& Birch Moonwomon eds., 1992).

${ }^{64} \mathrm{Id}$. at 148.

${ }^{65} I d$.; Susan Ehrlich, The Discursive Reconstruction of Sexual Consent, 9 DisCOURSE \& SOC'Y 149 (1998); Susan E. Hickman \& Charlene L. Muehlenhard, "By the Semi-Mystical Appearance of a Condom." How Young Women and Men Communicate Sexual Consent in Heterosexual Situations, 36 J. OF SEX REs. 258 (1999).

${ }^{66}$ See generally Hickman \& Muehlenhard, supra note 65; Kristen N. Jozkowski, Zoë D. Peterson, Stephanie A. Sanders, Barbara Dennis \& Michael Reece, Gender Differences in Heterosexual College Students' Conceptualizations and Indicators of Sexual Consent. Implications for Contemporary Sexual Assault Prevention Education, 51 J. OF SEX RES. 904 (2014); Rachael O'Byrne, Susan Hansen \& Mark Rapley, "If a Girl Doesn't Say 'no....:"Young men, Rape and Claims of 'Insufficient Knowledge', 18 J. of Community \& Applied Soc. Psychol. 168 (2008); Powell, supra note 50.

${ }^{67}$ Freed, supra note 63, at 149-50; O'Byrne et al., supra note 66, at 177.

${ }^{68}$ For an overview, see Melanie A. Beres, Rethinking the Concept of Consent for Anti-Sexual Violence Activism and Education, 24 Feminism \& Psychol. 373 (2014). See also, Melissa Burkett \& Karine Hamilton, Postfeminist Sexual Agency. Young Women's Negotiations of Sexual consent, 15 SEXUALITIES 815 (2012); Celia Kitzinger \& Hannah Frith, Just Say No? The Use of Conversation Analysis in Developing a Feminist Perspective on Sexual Refusal, 10 DISCOURSE \& Soc'Y 293 (1999); Powell, supra note 50.

${ }^{69}$ Kitzinger \& Frith, supra note 68 , at 297

${ }^{70} \mathrm{O}$ 'Byrne et al., supra note 66, at 177; see also Kitzinger \& Frith, supra note 68.

${ }^{71}$ Rachael O’Byrne, Mark Rapley \& Susan Hansen, 'You Couldn't Say "No," Could You?': Young Men's Understandings of Sexual Refusal, 16 Feminism \& Psychol. 133, 141 (2006).
} 
It can therefore be expected that rejections that are articulated according to all rules of everyday communication will also be understood in sexual situations. ${ }^{72}$ A direct and verbal question, as required by many affirmative consent regulations, in order to obtain explicit consent, creates an artificial situation that does not correspond to everyday conventions and makes it difficult for people to react adequately. Because people tend not to want to hurt their counterpart, and this is especially true for sexual situations due to their intimacy, they will find it difficult not to give a yes and will rather try to communicate their rejection indirectly. A direct question gives only limited space to formulate a "nice" rejection that conforms to social conventions and does not hurt the other person. Demanding direct, verbal communication can thus lead to increased pressure to give a socially desirable yes in terms of socially desirable behavior. Therefore, affirmative consent contains the more or less implicit requirement to express refusal directly and verbally, which does not reflect everyday conventions. ${ }^{73}$ In most cases, a direct no and also a direct yes is not necessary to express rejection or consent in a way that is understandable to the other party.

The famous verbal but indirect question "Would you like to come up for a drink?" offers all participants the opportunity to save face if the sexual advances are not reciprocated. It makes it easier for the invited side to refuse sex without explicitly expressing this and thus without the risk of hurting someone. By answering "No, I don't want another drink" one can pretend to ignore the sexual invitation or, if one is still unsure, accept the invitation and still withdraw after the drink without having to make the rejection explicit. This kind of indirect communication gives the participants the opportunity to hide their true intentions, provide them "with some protection from embarrassment or rejection" and still indicate them in a way that they can be understood. ${ }^{74}$

If people want to have sex that conforms with affirmative consent rules, they have to communicate verbally and directly. This ignores not only everyday communication conventions, but also the vulnerability and the resulting need for protection of the participants or their fear of hurting the other person. It thus tacitly relies on emotionally independent sexual subjects who are courageous enough to formulate direct questions, thus risking and, if necessary, accepting direct rejection.

Although in most cases an explicit "no" is not necessary to understand rejection, sexual assaults are often justified by the fact that the lack of consent was not perceived. In the study by O'Byrne et al., respondents justify assaults with "insufficient knowledge," even when direct and verbal communication took place:

By posing the rhetorical question, 'when does no mean no when does yes mean yes', Kyle [study participant, RT] draws on the fact that acceptances and refusals, even in their most direct forms of 'yes' and 'no', can be flexibly employed to achieve opposite effects (e.g. token refusals and token acceptances) .... This works to construct sexual refusals, even apparently clear and direct refusals, as ambiguous 'signals' and therefore as readily subject to misinterpretation. ${ }^{75}$

Interesting in the quotation is that here the participant of the study describes not only clearly formulated refusal— "when does no mean no"-as ambivalent, but also agreement—-when does yes mean yes." In the case a sexual offense is claimed to be a misunderstanding, it seems to be irrelevant whether consent or rejection was communicated directly or indirectly. It can be concluded "that young women are communicating in ways which are usually understood to mean refusal in other contexts and it is not the adequacy of their communication that should be

\footnotetext{
${ }^{72}$ Kitzinger \& Frith, supra note 68 , at 308.

${ }^{73}$ Kitzinger \& Frith, supra note 68.

${ }^{74}$ Kirsten P. Lindgren, Michele R. Parkhill, William H. George \& Christian S. Hendershot, Gender Differences in Perceptions of Sexual Intent. A Qualitative Research and Integration, 32 Psychol. of Women Q. 423, 423 (2008).

${ }^{75}$ O'Byrne et al., supra note 66 , at $178-79$.
} 
questioned, but rather their male partners' claims not to understand that these women are refusing sex."76

The explanation of sexual violence with miscommunication should therefore be understood as a myth that favors rather than elucidate sexual violence. ${ }^{77}$ The cause of sexual violence is not so much about perpetrators who do not understand sexual refusal, but that they "do not like" it. ${ }^{78}$ The assumption that the reason for sexualized violence is miscommunication, which can be eliminated through clearer communication, can reinforce narratives of justification from perpetrators who present sexual offenses as unintentional.

\section{E. The Problem of Sexual Compliance}

Sexual compliance is understood as behavior "in which a person freely consents to sexual activity with a partner without experiencing a concomitant desire for the initiated sexual activity." 79 Many people have already agreed to unwanted sex and thereby practiced sexual compliance. Depending on the study, the figures vary widely between thirty-five and ninety-seven percent of those surveyed and are higher for women overall.$^{80}$ In general, frequent reasons for sexual compliance are the satisfaction of the partner's needs, the desire to stabilize the partnership, a sense of sexual duty based on certain ideas of relationships, social recognition, fear of relationship conflicts, and other reasons that are coupled with heteronormative discourses and sometimes exhibit different genderspecific distributions. ${ }^{81}$ Therefore, heteronormative discourses, which include traditional gender roles of female caring and the underrepresentation of female desire can be named as reasons why women are more likely to exhibit compliance behavior.

Various studies have found that women in particular find it difficult or impossible to refuse sex simply because they have put themselves in a certain situation. ${ }^{82}$ For example, a female participant in one study described how she considered it consenting to sex to enter a boy's apartment alone:

Well, the fact that I was there and wasn't telling my friend to take me home or telling one of the guys there that was sober to take me home, you know .... Kind of by not making a big deal out of, like being alone in there with him ... . You know, by staying and by not saying anything about the awkward situation of being alone in there with a guy that I just met like twice before, that was kind of like consenting to it. ${ }^{83}$

For this reason, she did not consider the subsequent sex to be rape, although she even said no during the course of the encounter. However, very few women seem to do so. When women flirt, allow or initiate certain physical contact, ride in a boy's car, let him take her home, have drinks and the like, this can lead to them feeling obliged to engage in sexual acts. ${ }^{84}$ They describe this like a "point of no return"- a point at which they cannot go back, because they have "gone along" so far.

\footnotetext{
${ }^{76}$ Kitzinger \& Frith, supra note 68 , at 309-10.

${ }^{77}$ O'Byrne et al., supra note 66, at 189.

${ }^{78}$ Kitzinger \& Frith, supra note 68, at 309-10.

${ }^{79}$ Lucia F. O'Sullivan \& Elizabeth Rice Allgeier, Feigning Sexual Desire: Consenting to Unwanted Sexual Activity in Heterosexual Dating Relationships, 35 J. OF SEX REs. 234, 234 (1998).

${ }^{80} I d$. at 235; Emily A. Impett \& Letitia A. Peplau, Sexual Compliance. Gender, Motivational, and Relationship Perspectives, 40 J. OF SEX RES. 87, 88-89 (2003).

${ }^{81}$ Impett \& Peplau, supra note 80, at 92-93; Eva-Verena Wendt, Uneindeutige Kommunikation sexueller Absichten bei jungen Paaren, 23 ZeITSChrift FÜr SEXUALForschung 220, 223 (2010).

${ }^{82}$ Gavey, supra note 35, at 333-34; Powell, supra note 50, at 178; Burkett \& Hamilton, supra note 68, at 823-24.

${ }^{83}$ Zoë D. Peterson \& Charlene L. Muehlenhard, Conceptualizing the "Wantedness" of Women's Consensual and Nonconsensual Sexual Experiences: Implications for How Women Label Their Experiences with Rape, 44 J. OF SEX RES. 72 , 83 (2007).

${ }^{84}$ Burkett \& Hamilton, supra note 68 , at $822-23$.
} 
It seems plausible that certain situations within heterosexual encounters are perceived by women as a de facto compulsion to have sex without direct pressure from the sexual partner. ${ }^{85}$

The same can be said for sex within intimate relationships. Negotiations of consent are here also influenced by social norms that promote consent to unwanted sexual acts. Women report that, on the assumption that in a-heterosexual-relationship one has to have sex at a certain frequency, they sleep with their boyfriend even if they do not feel like it. ${ }^{86}$ They often feel guilty when they are not sexually available. Even if they assume that it would not be a problem to refuse sex, these feelings of guilt can lead them to still feel obliged to satisfy their boyfriend. This is especially true-corresponding to the male sexual drive discourse-in situations where they perceive their partner as sexually aroused. ${ }^{87}$ Often women also describe it as an act of love or to do their partner a favor: "It might not be that they're pressuring you, it might just be like you love them so much that you just want to do anything for them and make them happy." 88 This description corresponds to traditional gender roles, by which women should put the needs of others above their own in the sense of care and empathy. Additionally, it refers to the have/hold discourse, in which women are seen as those who do not satisfy their own desires through sex but want to create closeness and commitment in a relationship.

But not only women can participate in unwanted sexual acts due to restrictive gender roles and heteronormative rules. For example, men may feel pressured to initiate sex in order to prove their masculinity, because male sexuality is constructed as active, desiring and sometimes aggressive. In one study two young men describe very explicitly the influence of societal expectations on their sexual behavior:

Joel (18 years): It's just taking the initiative, we've just got to be the one to find the spark, and they're the person that just sits back and enjoys it, I mean, it's like there's an unwritten rule that the guy's meant to show her a good time, if you know what I mean.

Dan (20 years): Just the pressures, the external pressures I guess, you know expectations to be cool. You've got to be doing that, you've got to be treating girls badly and you know kissing them or whatever and just forgetting them, scoring I guess. ${ }^{89}$

The mere anticipation of an obligation is sufficient here for women and men to consent to sexual acts that they do not want to perform. In this context, Powell points out that male domination is not only secured by physical violence, but also by "symbolic violence," in that traditional gender norms and patriarchal values are accepted as "normal" and "natural." This "symbolic violence" often takes place on a preconscious level: “[W]hile an individual may say 'I consented,' the gendered rules of the game or structure of the field of heterosexual encounters, actually precludes assertive sexual refusal in many instances." 91 This means that social actors in symbolic violent relationships make a virtue of necessity: They reject what they are denied anyway or-as in this case - "choose" the inevitable. ${ }^{92}$ This is exactly what women describe when they talk about being at a point where, due to certain actions, it comes down to sex and this seems to be inevitable for them. Studies also describe that women agree for fear that their "no" is not heard. ${ }^{93}$ In order not to have to acknowledge the unwanted sex afterwards as rape, they do not resist, but fake their will to

\footnotetext{
${ }^{85}$ Gavey, supra note 35 , at 337-39; Beres, supra note 68 , at 382.

${ }^{86}$ See e.g. Gavey, supra note 35 , at 332; Burkett \& Hamilton, supra note 68, at 825-26.

${ }^{87}$ Burkett \& Hamilton, supra note 68 , at $826-27$.

${ }^{88}$ Powell, supra note 50, at 176; Burkett \& Hamilton, supra note 68, at 825; Gavey, supra note 35, at 343.

${ }^{89}$ Powell, supra note 50 , at 176 .

${ }^{90} \mathrm{Id}$. at 173.

${ }^{91} I d$.

${ }^{92} I d$. Bourdieu calls that amor fati - the love of fate.

${ }^{93}$ Gavey, supra note 35, at 334; Powell, supra note 50 at 175.
} 
have sex: "Because there is always that fear that you could say no and it would carry on anyway, and, and being physically less, and then you'd be raped sort of thing, and then it would be terrible." 94 This is a particularly perfidious situation. For fear that a "no" would have no effect, consent to unwanted sex is given. The described fear that the other person will not listen to a no can also occur in an affirmative consent situation. Out of fear that a non-existent yes-which is nothing more than a no in the context of affirmative consent-is passed over, consent is given. In the trial against Harvey Weinstein, one of the witnesses said about him: "If he heard the word 'no,' it was like a trigger for him." 95

In this context, it is important to emphasize the influence that female socialization can have on how threatening women perceive certain situations and what consequences this has for both their actions and inactions. Susan Ehrlich shows in her analysis of a sex crime trial how one of the plaintiffs repeatedly tried to make it clear that she was afraid that the defendant would hurt her and that she therefore avoided screaming, fleeing or sending him away:

Marg [the accuser, RT] acted in ways that (she believed) would minimize her risk of physical violence and injury. Thus, it is not that her behavior is lacking in resistance; rather she can be seen as considering possibilities for action given the restricted options available to her, and as actively negotiating relations with the defendant in order to prevent further and more extreme instances of violence. ${ }^{96}$

Ehrlich concludes that women perceive sexual situations differently because they are affected in a different way by sexual violence, especially by men, and these perceptions result in different ways of acting. This must be taken into consideration when trying to classify supposed signals of sexual consent. ${ }^{97}$ In her discourse analysis on rape, the cultural scientist Mithu Sanyal points out that the constant warning against rape for women is one of the "initiations into gender relations." 98 As a result, girls and women learn that they are "rapeable" and vulnerable and should behave accordingly in a preventive manner. This can be understood as an internalization of the victim blaming discourse, according to which women are, partly, responsible for the violence that happens to them through their behavior.

In addition, there is a post-feminist discourse that-in the sense of a modern, enlightened, "sex-positive" attitude-generally considers sex to be good and desirable for women. It constructs the image of the emancipated, empowered woman, "a young, attractive, heterosexual woman who knowingly and deliberately plays with her sexual power and is always 'up for' sex." 99 The combination of empowerment and "always up for sex" leads to contradictions. Saying "yes" becomes desirable and can work as a proof to be empowered, modern, attractive and have a fulfilled sex life. The socially dominant image of "Girl Power" conveys that women have the individual choice and power to stand up for their needs. However, it also denies the impact of sexual and gender norms on these choices. As a result, women present their actions as self-chosen and free decisions. ${ }^{100}$ In the light of the permissive discourse, the requirement for women to be modern and "up for sex" is also a double bind. At the same time, they should not be too demanding and should express their desire too explicitly. In this way they run the risk of being labeled as "whores."101

\footnotetext{
${ }^{94}$ Gavey, supra note 35 , at 334 .

${ }^{95}$ Harvey Weinstein Trial: Accuser says 'No' was a Trigger for him, BBC NEws, Jan. 31, 2020, https://www.bbc.com/news/ world-us-canada-51324741.

${ }^{96}$ Ehrlich, supra note 65, at 165-67.

${ }^{97} I d$.

${ }^{98}$ Mithu M. Sanyal, Vergewaltigung: Aspekte eines Verbrechens 12 (2016).

${ }^{99}$ Rosalind Gill, Culture and Subjectivity in Neoliberal and Postfeminist Times, 25 SubjeCtivity 432, 437 (2008).

${ }^{100}$ Burkett \& Hamilton, supra note 68 , at 829.

${ }^{101}$ Katherine Angel, Sex and Self-Knowledge: Beyond Consent, Verso BLOG, Feb. 14, 2020, https://www.versobooks.com/ blogs/4573-sex-and-self-knowledge-beyond-consent.
} 
Heteronormative discourses go hand in hand with powerful self-constraints that can limit the options for action in sexual encounters, especially for women. An affirmative consent standard makes power relations beyond obvious constraints invisible. Affirmative consent suggests that every "yes" really means "yes". However, as shown above, heteronormative discourses as well as traditional and modern gender images can promote consent to unwanted sex in casual sexual encounters as well as in love relationships. Especially women, but also men, participate more or less actively in unwanted sexual acts and agree to them. The fact that women and men have different options to act under the given social conditions must be recognized without automatically assigning women a victim status. In each individual case, it must be decided in a gender-and heteronormativity-sensitive assessment of the respective circumstances which options for action were available to both the victims and the accused and what consequences this has for the assessment of whether sexual consent existed.

\section{F. Conclusion}

On the one hand, sexual consent must be located in a gendered and heteronormative context and its impact has to be recognized. On the other hand, it must also acknowledge and take seriously the subjective experiences of women, their power of action and autonomy in their-primarily hetero-sexual negotiations. Every woman makes her own subjective experiences with and in her sexuality and thus also with the negotiation of sexual consent.

But what does that mean in more concrete terms? It is important to reflect on the different scopes of action for hetero-, homo-, and bisexual men, women, and trans in sexual encounters. At the same time, it is important to understand these scopes of action as structured by gender inequalities and heteronormativity. Heteronormativity as well as gender are always tendencies. They are always important, but with different impacts on contexts, situations and experiences. It is particularly relevant for a discussion on affirmative consent to make gender and heteronormativity relevant categories, which are not only working as pressures "from outside" but as norms, which are also internalized in us as sexual subjects. Power not only negatively determines the subjects through restriction and prevention, but it creates the subjects in the first place and these in turn constantly co-create themselves and power. In this respect, people have scope for action which, depending on how it is used, can shift, undermine, or stabilize power relations. Against this background, it makes perfect sense to look for existing scopes of action and to think about how they can be expanded. "Yes means Yes" can be regarded as such a search. At the same time, the available options for action are already structured by power relations. Or to put it differently, there is no action beyond power. This also means that power does not only unfold its effects through external coercion and repression, but also in the form of techniques of self-care, self-regulation and self-control. In the concept of affirmative consent precisely these self-techniques of power are insufficiently reflected. Women in particular, through internalized femininity requirements, agree to sex they actually do not want. Thus, the implication of affirmative consent, that a "yes" given without external pressure would result in unproblematic sex, must be questioned. It can obscure the view of the structural violence of heteronormative sexuality and the internalization of gender-specific attributions.

The concept of affirmative consent is based on a giver-receiver-grammar-one person receives consent and another gives it. Such an understanding of consent corresponds to heteronormative concepts of male sexuality as active-initiating and female sexuality as reactive-receptive and can reproduce them. This coincides with the male sexual drive discourse, according to which men always want sex-consent is thus automatically assumed by them. Thus, male desire is set centrally. The responsibility for border violations is shifted one-sidedly to the, male-connoted, receiver side. This can contribute to a selective perception of sexualized violence, according to which women cannot violate the boundaries of men. Additionally, those conceptions can stabilize 
traditional gender roles of female vulnerability, powerlessness, and potential victimhood, as well as male protection, power to act, and potential perpetration.

Affirmative consent requires permanent negotiations between the participating individuals within sexual encounters. These requirements consequently presuppose individuals who are able and willing to articulate their wishes and intentions directly and thus ignores the potential vulnerability of those involved. The responsible and rational planning of sexuality is considered desirable. This corresponds to individualistic ways of thinking and neoliberal ideas of planning, competition and regulation. In contrast, people who are insecure, dependent, unwilling or unable to communicate their wishes can become incompetent sexual actors. This ultimately places the responsibility for sexual consent in the hands of the individual participants and thus individualizes them. This misjudges the overall social context and the power relations between the participants. In the affirmative consent approach, people are understood as rational, autonomous subjects and thus it fails to recognize their locatedness in heteronormative gender relations.

On the one hand, the concept of affirmative consent is thus too liberal. On the other hand, affirmative consent is at the same time not liberal enough and too morally charged.

Legal experts will have to answer the question of what a meaningful legal definition of consent in sexual criminal law can look like. In any case, I argue for a contextualized understanding of consent that takes gender inequalities and heteronormative discourses into account. It is about a political recognition of differently available freedoms and dependences in sexuality that have an impact on how we negotiate sexual consent, which can limit or empower us - or bothand which are too often underacknowledged.

Cite this article: Torenz R (2021). The Politics of Affirmative Consent: Considerations from a Gender and Sexuality Studies Perspective. German Law Journal 22, 718-733. https://doi.org/10.1017/glj.2021.33 